\title{
Ballooning spiders (Araneae) over the forest island in an agricultural landscape of Wielkopolska
}

\author{
Maria OLESZCZUK and Jerzy KARG
}

\begin{abstract}
Institute for Agricultural and Forest Environment, Polish Academy of Sciences, Field Station, Szkolna 4, Turew, 64-000 Kościan,Poland; e-mail: oleszczukm@vp.pl,jerykarg@man.poznan.pl
\end{abstract}

\begin{abstract}
The paper presents the data on ballooning spiders' number and taxonomic composition caught on the height of $46 \mathrm{~m}$ above the ground in a mosaic agricultural landscape. The samples were collected from April to October 2009. The trap was placed on the meteorological tower over the midfield forest island in the village of Turew, Wielkopolska region in western Poland. 60 spider specimens were collected, represented by six families and seven species. The Linyphiidae was the most abundant. Juvenile specimens constituted $78 \%$ of all recorded specimens. However, adult and quite large in body size Anyphaena accentuata and Philodromus praedatus were also recorded. Seasonal dispersion of families and species is discussed.
\end{abstract}

Key words: aerial dispersal, spiders, farmland, midfield woods, habitat island

\section{INTRODUCTION}

The spiders' ability to move in the air with gossamer (spider silk) have been known for many species. This phenomenon is associated mainly with early autumn but it can also be observed from spring to late autumn and even in winter. Spiders that prefer aerial dispersal are known as aeronautic species. They are mainly small in size (few $\mathrm{mm}$ ). However, species which are more than $10 \mathrm{~mm}$ in size can also move this way, especially as immature specimens. Spiders are able to disperse in the air for considerable distances (hundreds of kilometers) and survival of a migrating specimen depends on where it lands. If the habitat is unsuitable the spider dies.

Agricultural landscape is characterized by large open areas, favoring aerial migration. Uncultivated habitats like: midfield woods, bushes, balks and bodies of water are reservoirs of species diversity of fauna and flora. After intensive farming practices the small soil fauna has been completely destroyed and recolonisation of cultivated fields occurs from perennial habitats (Topping \& Sunderland 1994, Schmidt \& Tscharntke 2005).

Dezydery Chlapowski Landscape Park, which has a typically agricultural character, is abundant in shelterbelts increasing biodiversity and landscape diversity in this terrain. The unique midfield forest island in the area is a park surrounding the palace in the village of Turew. In the central part of the park forest there is a tower which was build in 1995 and it is used for permanent monitoring of microclimatic parameters. A trap is situated on the top of the tower (16 meters above the tree canopy) which was used for monitoring of insect and spider aerofauna.

In the area of the Dezydery Chlapowski Landscape Park 194 spider species have been stated so far (Euczak 1974, Wolak \& Karg 2002, Kajak \& Oleszczuk 2004, Oleszczuk 2010). The studies concerned epigeic and horto-biont spiders. There is no information about spiders migrating in the air on this area. The only paper on aerial migration contains share of spider families and species as well as phenological data on passive dispersal of spiders in meadows (Kajak 1959). 
A different issue is the research methodic of ballooning spiders. In all known studies samples were taken with a usage of different kinds of traps: sticky traps, suction traps. Spiders were also collected just before "starting", when they were climbing on the highest places in the area. The traps operated several $\mathrm{cm}$ to $2.5 \mathrm{~m}$ above the ground. The method of catching spiders present in aeroplankton described in this paper is unique because of large height and construction of the trap.

The aim of the study was to asses taxonomic composition and the number of spider moving by air high above tree canopy in an agricultural landscape through one vegetative season.

\section{MATERIAL AND METHODS}

The study area is located on the Wielkopolska lowland, $40 \mathrm{~km}$ south of Poznan, in the Dezydery Chlapowski Landscape Park. Crop fields and grasslands cover about $74 \%$ of the Park area, with woodland constituting about $15 \%$. Woods are numerous, but highly fragmented. Samples were taken in the area of midfield forest island: the palace park in the village of Turew. The park is located in the central part of the Dezydery Chlapowski Landscape Park and its area amounts $20 \mathrm{ha}$. It is divided into two parts differing in the way of management. An unmanaged part is overgrown by oak-hornbeam forest (Galio silvatici-Carpinetum) and riparian forest (Ficario-Ulmetum). The managed part of the park contains forested areas, lawns, meadows, flowerbeds and alleys (Karg \& Kujawa 1996).

The spiders were taken with the use of trap at the top of the meteorological tower $46 \mathrm{~m}$ in height and $16 \mathrm{~m}$ above the tree canopy. The trap was a kind of sweep-net, $25 \mathrm{~cm}$ of diameter, made of tiny mesh, and turning with the wind in all directions. The sweep-net was connected with a container filled in $1 / 3$ with ethylene glycol, serving as preserving fluid.

The studies were carried out continuously from 3 April to 30 October 2009. Spiders were taken out every two weeks through the whole study period. Specimens were identified to species but juveniles often only to family level.

The data on spiders caught in the trap were collected in the years 1996-2001, but the specimens were counted in total as an order Araneae, without identification to lower taxonomical units (Karg - unpubl.). Spiders recorded in 2009 were identified to species level.

Tab. 1. List of the spider species ballooning in 2009 .

\begin{tabular}{|c|c|c|c|c|}
\hline Family/Species & Males & Females & Juveniles & Total \\
\hline Theridiidae & & & 11 & 11 \\
\hline Neottiura bimaculata (Linnaeus, 1767) & & & 1 & 1 \\
\hline Theridion sp. & & & 4 & 4 \\
\hline Linyphiidae & & & 19 & 19 \\
\hline Araeoncus humilis (Blackwall, 1841) & 1 & 2 & & 3 \\
\hline Meioneta murestris (C.L.Koch, 1836) & 1 & 5 & & 6 \\
\hline Porrhomma pygmaeum (Blackwall, 1834) & & 1 & & 1 \\
\hline Tetragnathidae & & & & \\
\hline Pachygnathasp. & & & 2 & 2 \\
\hline Araneidae & & & & \\
\hline Araniella sp. & & & 1 & 1 \\
\hline Mangora acalypha (Walckenaer, 1802) & & & 5 & 5 \\
\hline Anyphaenidae & & & & \\
\hline Anyphaena accentuata (Walckenaer 1802) & 2 & & & 2 \\
\hline Philodromidae & & & & \\
\hline Philodromus praedatus (O.-P.Cambridge 1871) & 1 & & & 1 \\
\hline Philodromus sp. & & & 3 & 3 \\
\hline Thomisidae & & & & \\
\hline Xysticus sp. & & & 1 & 1 \\
\hline In total & 5 & 8 & 47 & 60 \\
\hline
\end{tabular}




\section{RESULTS}

In total 60 spider specimens were collected, $78 \%$ of all were juveniles and $22 \%$ - adults (Table1). They were represented by six families and seven species. Among adults eight females and five males were collected. Almost half of all specimens was represented by the family Linyphiidae - tiny aeronautic species. Spiders that use the web to catch prey constituted $88 \%$ of the total. They belonged to the families Linyphiidae, Theridiidae, Araneidae and Tetragnathidae. The other families contained spiders hunting without webs (Fig. 1).

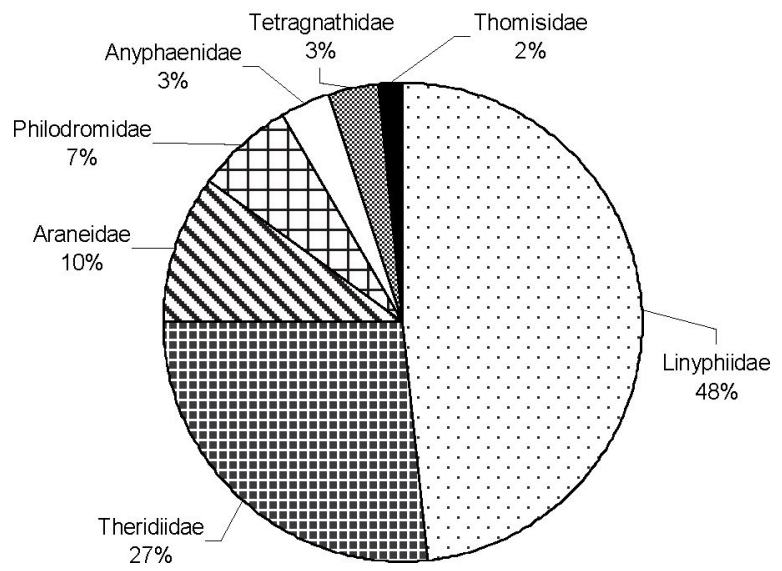

Fig. 1. Shares of spider families recorded in the year 2009.

Single spider specimens were caught through the whole study period but mostly in late summer. The peak of total spiders was stated in August (Fig. 2). In the years 1996-2001 the total number of collected spiders was not large: from 18 specimens in 1997 to 70 specimens in 1998, but in all seasons the largest number of spiders was also noted in August (Karg - unpubl. data). The peak of Linyphiidae occurred in June and it preceded the peak of theridiids in the end of August. The juveniles of Mangora acalypha Walckenaer from the family Araneidae were most abundant at the beginning of August as the Linyphiidae juveniles.
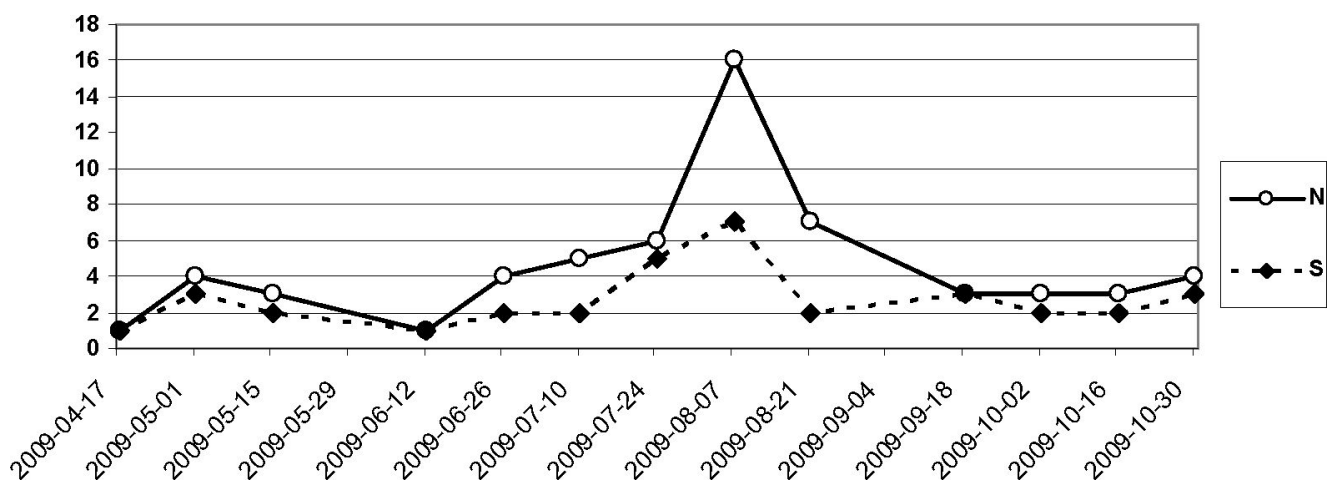

Fig. 2. Seasonal changes in number of specimens (N) and species (S) of spiders recorded in the year 2009. 
Although nearly all spider specimens, including adults, were small in size $(1,4-2,5 \mathrm{~mm})$, it is worth to mention that larger specimens, with body lengths from $5 \mathrm{~mm}$ to $7 \mathrm{~mm}$, were also stated. They were species of Anyphaena accentuata Walckenaer (two males) and Philodromus praedatus O. P.-Cambridge (one male). The latter one is on the "Red list of endangered and threatened animals in Poland" (Starega et al. 2002) with DD status. A. accentuata occurs on deciduous trees and $P$. praedatus on shrubs and trees.

\section{DISCUSSION}

The total number of spider specimens in present studies was rather small, similarly as in the earlier investigation, in the years 1996-2001. The cause of low number might be the large height of spiders' catching. The results obtained by Thorbek et al. (2002) support this as in the trap placed on the height of $12.2 \mathrm{~m}$ there were much less spider specimens noted than on the height of $1.4 \mathrm{~m}$ above the ground. The authors explained this with the fact that more spiders balloon near to the ground.

In our results the majority comprised juvenile specimens, as in all earlier studies of aerial dispersal of spiders (Duffey 1998, Thomas \& Jepson 1999). The opposite results were obtained by Blandenier \& Fürst (1998). However, the spider aeroplankton mostly consists of juveniles which, being smaller, find it easier to balloon, but they are difficult/impossible to identify to species level. There are a few factors influencing ballooning dispersal, e.g., strength, regularity and direction of wind, biological character of barriers, spider size, biology and physiological adaptations to stress. Various habitats provide different aerial dispersal possibilities. Leaf-litter, for instance, are poorer candidates for ballooning than are open-area or tree-canopy inhabitants. The effectiveness of ballooning dispersal and the taxonomic composition of aeronauts also differ, depending on the area (Żabka \& Nentwig 2000).

The family and species composition of spiders noted in this paper were similar to other studies, but the proportions in abundance of families are different. However, in both cases the most abundant was the family Linyphiidae, known as the richest in species in Poland (Rozwalka \& Stańska 2008). They are characteristic by perfecttly able of ballooning for considerable distances, especially into areas that have been disturbed by agricultural processes. Agrobiont spiders are known from their ability of colonization disturbed areas. In crop fields of Poland they are: Oedothorax apicatus, Erigone atra, $E$ dentipalpis, Meioneta rurestris, Araeoncus humilis. Particular dispersal strategies may allow some species to cope better with the agricultural landscape, which is characterized by a heterogeneous environment and fairly frequent high-mortality "catastrophes" (Johnson 2010). In our research the most abundant species among linphiids was Meioneta rurestris C. L. Koch (Table 1), similarly as in the studies carried out by Thomas \& Jepson (1999).

In this study the abundant families were in turn: Theridiidae, Araneidae, Philodromidae. Theridiidae is the second richest in species family in Poland (63 species), which small body sizes allow them to balloon. Neottiura bimaculata L. and Phylloneta impressa L. Koch, belonging to this family, very often inhabit crop fields. The abundant theridiid spiders might have also originated from the canopy of forest island, as the trap net was placed above the trees. In the forest canopy studied in Germany theridiids dominated (Otto \& Floren 2010). Spiders observed at high altitudes move by vertical ballooning and they originate more from the local fauna than from distant places (Szymkowiak et al. 2007).

In this study Mangora acalypha appeared the most abundant species of the family Araneidae. It is common speces occurring in crop plants, especially cereals. It occurs in the fields situated close to forests and shelterbelts (Luczak 1974, Oleszczuk - unpubl.). Similar 
preferences have species of the genus Philodromus, which were captured in field-forested strips ecotones (Oleszczuk - unpubl. data).

Abundance of spider families differed in other studies. In Switzerland the family Philodromidae was on the second position and theridiids constituted only $3.51 \%$ (Blandenier \& Fürst 1998). In American studies the family Oxyopidae was among the most abundant aeronautic spider families (Salmon \& Horner 1977, Dean \& Sterling 1985, Greenstone et al. 1987).

Regarding body size of aeronautic spiders, the majority of spiders were young and small in size. The adults were first of all tiny linyphiids, as in many other studies, e.g. conducted by Greenstone at al. (1987). The ability to balloon has been known for many adults in the Linyphiidae family (Salmon \& Horner 1977). However, in our studies, quite large in size adult ballooning spiders were stated: Anyphaena accentuata and Philodromus praedatus. The same species were caught by Blandenier and Fürst (1998).

In the current study spiders moving in the air were observed from April to October. They were mainly single adult specimens. An increase in number of immature linyphiids was observed twice: in June and in the beginning of August. In autumn the number of linyphiids, both juveniles and adults, only slightly increased. In the second half of the August the most numerous were theridiids. Blandenier \& Fürst (1998) in Switzerland noted one peak in June-July and the second in September and October. The peaks were caused by the large abundance of Linyphiidae, and, depending on the study season, young or adults spiders were noted. In England, Sunderland (1987) noted peaks in the number of ballooning spiders in July and in October. In our results there was no peak in the autumn months. It might have shifted to August. Kajak (1959) observed on two meadows that the majority of dispersing spiders belonged to the families Thomisidae and Lycosidae. He also noted that in the first year the largest intensity of dispersion was in the end of August and in the beginning of September but in the second year - from the half of September to October. Therefore, the time of major intensity of aerial dispersal may by different, depending on the year. Probably it is connected with weather conditions; warm, dry weather favors aerial dispersal the most (Duffey 1998). In turn, in autumn and spring weather conditions are usually unsuitable for ballooning and therefore, allow only short distance dispersal close to the groud (Toft 1995).

As the present study was carried out only in one year, further detailed and long-term research of aerial dispersal is needed.

\section{REFERENCES}

BLANDENIER G. \& FÜRST P.-A. 1998. Balloning spiders caught by a suction trap in an agricultural landscape in Switzerland. In: SELDEN P. A. (ed.), Proceedings of the $17^{\text {th }}$ European Colloquium of Arachnology, Edinburgh, 1997, pp. 177-186. British Arachnological Society, Buckinghamshore.

DEAN D. A. \& STERLING W. L . 1985. Size and phenology of ballooning spiders at two locations in eastern Texas . The Journal of Arachnology $13: 111-120$.

DUFFEY E. 1998. Aerial dispersal in spiders. In: Selden P. A. (ed.), Proceedings of the $17^{\text {th }}$ European Colloquium of Arachnology, Edinburgh, 1997, pp. 187 - 191. British Arachnological Society, Buckinghamshore.Proceedings of the 17th European Colloquium of Arachnology, Edinburgh.

Greenstone M. H. \& Morgan C. E., Hultsch A -L., FArRow R. A., Dowse J.E. 1987 . Ballooning spiders in Missouri, USA, and New South Wales, Australia: family and mass distributions. The Journal of Arachnology $15: 163-170$.

JOHNSON L. R. 2010. Implications of dispersal and life history strategies for the persistence of Linyphiid spider populations. Ecological Modelling 221 (8): 1138-1147.

KAJAK A. 1959. Uwagi w sprawie jesiennych wędrówek pająków. Ekologia Polska, ser. B, 5 (4): 331-338.

KAJAK A. \& OLESZCZUK M. 2004. Effect of Shelterbelts on adjoining cultivated Fields: patrolling intensity of carabid beetles (Carabidae) and spiders (Araneae). Polish Journal of Ecology 52 (2): 155-172.

KARG J. \& KUJAWA A. 1996. Zabytkowy park palacowy w Turwi - porównanie stanu drzewostanu na przestrzeni 15 lat. Biuletyn Parków Krajobrazowych Wielkopolski. Poznań 1 (3): 51-61. 
LUCZAK J. 1974. Ecological groups of spiders on potato and rye fields. Bulletin de l'Academie Polonaise des Sciences. Série des sciences biologiques, Cl. II, 22: 377-383.

OLESZCZUK M. 2010. Refugia śródpolne jako siedliska rzadziej spotykanych i zagrożonych gatunków pająków (Araneae) w Polsce. Chrońmy Przyrodę Ojczystą. 66 (5): 361-374.

OTTO S. \& FLOREN A. 2010. The canopy spiders (Araneae) of the floodplain forest in Leipzig. Arachnologische Mitteilungen 39: 25-38.

Rozwałka R. \& Stańska M. 2008. Check-list of spiders (Araneae) of Poland: http:/www.arachnologia.edu.pl/arachnopage/pliki/araneae_checklist-01.12.doc

SALMON J.. T.. \& HORNER N. V. 1977. Aerial dispersion of spiders in North Central Texas. The Journal of Arachnology 5:153-157.

SCHMIDT M.H. \& TSCHARNTKE T. 2005. The role of perennial habitats for Central European farmland spiders. Agriculture, Ecosystems and Environment 105: 235-242.

STARĘGA W., BŁASZAK C. \& RAFALSKI J. 2002. Arachnida Pajęczaki. Czerwona lista gatunków. In: GŁOWACIŃSKI Z. (red.), Czerwona lista zwierząt ginących i zagrożonych w Polsce, pp. 133-140. Instytut Ochrony Przyrody PAN, Kraków, 155 pp.

SUNDERLAND K. D. 1987: Spiders and cereal aphids in Europe. Bulletin IOBC/WPRS: 10: 82-102.

SZYMKOWIAK P., GÓRSKI G. \& BAJERLEIN D. 2007. Passive dispersal in arachnids. Biological Letters 44 (2): $75-101$.

TOFT S. 1995. Two functions of gossamer dispersal in spiders? Acta Jutlandica 70, 257-268.

THOMAS C. F. G. \& JEPSON P. C. 1999. Fifferential aerial dispersal of Linyphhid spiders from a grass and a cereal field. The Journal of Arachnology 27: 294-300.

THORBEK P., TOPPNNG CH. J. \& SUNDERLAND K. D. 2002. Validation of a simple method for monitoring aerial activity of spiders. The Journal of Arachnology 30: 57-64.

TOPPING C. J. \& SUNDERLAND K. D.1994. A spatial population dynamics model for Lepthyphantes tenuis (Araneae: Linyphiidae) with some simulations of the spatial and temporal effects of farming operations and land use. Agriculture, Ecosystems and Environment 48: 405-430.

WOLAK M. \& KARG. J. 2002. Pająki zimujące w zadrzewieniach śródpolnych. In: BANASZAK J. (ed.), Wyspy Środowiskowe. Bioróżnorodność i próby typologii, pp. 147-158. Wydawnictwo Akademii Bydgoskiej im. Kazimierza Wielkiego, Bydgoszcz, 302 pp.

ŻABKA M. \& NENTWIG W. 2000. Salticidae (Arachnida: Araneae) of the Krakatau Islands (Indonesia). A preliminary approach. Ekologia (Bratislava) 19, Suppl. 3: 293-306.

\section{STRESZCZENIE}

\section{[Pająki Araneae migrujące drogą powietrzną nad wyspą leśną w krajobrazie rolniczym Wielkopolski]}

Praca przedstawia dane dotyczace liczebności oraz składu taksonomicznego pajaków przemieszczających się drogą powietrzną na wysokości 46 metrów nad ziemią w mozaikowym krajobrazie rolniczym. Próby pobierano od kwietnia do października 2009 roku za pomoca pułapki umieszczonej na wieży meteorologicznej nad śródpolną wyspa leśną w Turwi, położonej w Parku Krajobrazowym im. gen. D. Chłapowskiego w Wielkopolsce. Ogółem stwierdzono 60 osobników pająków, reprezentowanych przez sześć rodzin i siedem gatunków. Dominowaly wśród nich pająki z rodziny Linyphiidae. 78\% wszystkich stwierdzonych pajaków stanowily okazy młodociane. Jednakże obecne były w próbach także dorosłe osobniki o względnie dużych rozmiarach ciala: Anyphaena accentuata i Philodromus praedatus. W pracy dyskutowane sa sezonowe aspekty dyspersji pajaków. 